\title{
Pemanfatan Media Moderen dalam Dakwah Islam dengan Pendekatan Religious Marketing
}

Oleh: Muhammad Mabrur, Lc., M.Ag

\begin{abstract}
Da'wah is currently facing a world that continues to move forward. He was in the middle of democratization which has guaranteed the rights and freedoms of individuals in behave. Supported by increasingly rapid technological development, particularly in the field of information, which has made it easier for anyone to access a variety of information. So at this point, there is no authority that can compel others to believe or do something. Even religious authorities, nor does it have the power to force anyone, as far as it concerns the behavior or beliefs of a personal nature.

It is undeniable that the media have a strong influence in the marketing process. But please note that although the media have an important position, he will not be able to move itself. There are still some other component of 4Ps (Product, Price, Place and Promotion, added Process), which also need to be considered and taken into consideration.
\end{abstract}

Keywords: Media Modern, Islamic Da'wah, Marketing

\section{A. Pendahuluan}

Dakwah sebagai sarana sosialisasi dan transformasi nilai dan ajaran agama Islam, ketika dibatasi pada kegiatan ceramah atau pidato (dengan berbagai variasinya), sebagaimana yang umum difahami masyarakat ${ }^{1}$, akan dapat membatasi ruang gerak dan mempersempit makna dakwah itu sendiri, Sebagian masyarakat memahami bahwa kegiatan dakwah identik dengan kegiatan pidato. Memang diakui bahwa sampai saat ini ceramah atau pidato dengan berbagai variasi pengembangannya (seperti dialog interaktif, talk show dan beberapa variasi lainnya) menjadi sarana yang paling efektif dan mudah untuk dilakukan. Namun perkembangan tehnologi telah menuntutnya untuk terus bertransformasi. * Dosen Tetap “Tafsir” Fakultas Dakwah dan
Komunikasi IAIN Antasari Banjarmasin

1 Hamam 'Abdu al-Rahim, Qawa'id al-Da'wah ila Allah (al-Mans\}urah: Dar alWafa, 1989), p. 100.
Hal ini disebabkan karena Dakwah saat ini sedang menghadapi dunia yang terus bergerak maju. Ia berada di tengah arus demokratisasi yang telah menjamin hak dan kebebasan individu dalam berprilaku. Didukung dengan perkembangan tehnologi yang semakin pesat, hususnya di bidang informasi, yang telah memberikan kemudahan kepada siapapun untuk mengakses berbagai informasi. Maka pada saat ini, tidak ada lagi otoritas yang dapat memaksa masyarakat untuk meyakini atau melakukan sesuatu. Bahkan otoritas agama, tidak pula memiliki kekuasaan untuk memaksa siapapun, sejauh hal itu menyangkut prilaku atau keyakinan yang bersifat pribadi, yang mungkin dilakukan oleh para praktisi dakwah adalah menyampaikan nilai-nilai dan ajaran agama, sambil berusaha meyakinkan masyarakat, melalui pendekatan persuasive. $^{2}$ Agar kemudian dengan

2 Parlof mendefinisikan komunikasi persuasif sebagai suatu proses simbolik, di mana komunikator mencoba untuk meyakinkan seseorang, agar mau merubah sikap 
kesadaran yang dimiliki, mereka mau meyakini dan merealisasikan nilai atau ajaran agama, sesuai dengan apa yang telah diajarkan.

Menurut 'Ali al-Rifa'i Ni'matullah Ajaran Islam tidak mengajarkan penggunaan pemaksaan. Bahkan pada hal yang paling fundamental yaitu keimanan Maka manakala keimanan didasari oleh pemaksaan, keimanan tersebut tidak dapat diterima. ${ }^{3}$

Oleh karena itu menurut kalangan ulama pemanfaatan media dan tehnik modern untuk kepentingan dakwah agar dapat diterima masyarakat perlu dilakukan. Tanpa pengembangan konsep dan metode dakwah, maka dakwah akan redup di tengah pertarungan berbagai ajaran dan peradaban ${ }^{4}$.

Untuk itu, perlu dilakukan inovasi konstruktif ${ }^{5}$ dalam rangka mengelola opini publik agar ajaran agama dapat disampaikan, kemudian dapat diterima masyarakat, Sehingga Dakwah Islam bisa mendapatkan tempat dan tetap mengakar

dan prilakunya, sesuai dengan isu yang ditawarkan, melalui pemindahan pesan, dalam suasana bebas untuk melakukan pilihan. Richard M. Perlof, The Dynamics of Persuasion: Communication and Attitudes in the 21st Century (New Jersey: Lawrence Erlbaum Associates, Inc., 2003), 34. Baca pula: Dedy Djamaluddin Malik, Komunikasi Persuasif (Bandung:Remaja Rosdakarya,1994), p. 13.

3 'Ali al-Rifa'i Ni'mat Allah, alDa'wah ila Allah (Kairo: Matba'ah al-Husayn, 1992), p. 42

${ }^{4}$ Muh\}yi al-Din 'Abd al-Halim, Nahwa al-I 'lam al-'Islamy F>'il wa Muathir (Tripoli: Maktabah al-Islam, 2000), p. 202.

${ }^{5}$ Samir bin Jamil Rad\}i, al-I'lam alIslami, al-Risalah wa al-Hadaf (Makkah: Maktabah Rabitah al-'Alam al-Islamy, 1417), p. 48 di tengah masyarakat, di antara arus budaya modern yang ada.

Salah satu bentuk gagasan inovatif dalam dakwah yang telah dan banyak digunakan oleh beberapa lembaga berbasis agama pada saat ini, adalah penggunaan pendekatan marketing. ${ }^{6}$

\section{B. Hubungan Marketing dan Agama}

Agak rumit mencari hubungan antara agama dan marketing sebagai cabang disiplin ilmu ekonomi yang sekuler (walaupun sebenarnya beberapa konsep marketing dalam bentuknya yang pailng sederhana telah diaplikasikan dalam praktek dakwah). Dua hal yang memiliki wilayah berbeda. Agama memiliki karakter sakral sedangkan marketing yang dikenal selama ini, berkarakter profan. Dua hal yang dianggap berada pada dua sisi yang berseberangan. Namun menurut Mc. Danniel, sebagaimana dikutip oleh Mara Eisntein, bahwa asumsi ini tidak lagi dapat dipertahankan. Karena pada saat ini, agama dan marketing memiliki hubungan yang dapat memberikan keuntungan untuk saling memberikan masukan pada yang lainnya.

Agama dapat menggunakan prinsip-prinsip marketing dalam mensosialisasikan ajarannya. Begitu pula sebaliknya, pakar marketing dapat mempelajari prinsip-prinsip prilaku beragama, dalam memahami karakter prilaku konsumen. Dalam beberapa

6 . Mara Einstein, Brands of Faith: Marketing Religion in a Commercial Age : Religion, Media and Culture (Canada: Taylor \& Francis Routledge, 2008), p. 75-78 
kasus, hubungan dan kemiripan antara dua hal ini akan dapat terlihat. Di antaranya adalah, ketika seseorang menganut suatu ajaran agama, itu berarti ia telah mempercayai sistem ajaran yang ditawarkan. Selanjutnya mereka mengekspresikannya dalam bentuk ritual. Sedangkan dalam marketing, ketika konsumen menggunakan suatu produk, itu berarti ia telah mempercayai brand produk yang ditawarkan

Pakar marketing Kotler, mendefinisikan marketing sebagai proses sosial yang dilakukan individu atau kelompok, untuk memenuhi kebutuhan dan keinginan melalui penciptaan, pemindahan serta pertukaran produksi dan pelayanan yang bernilai kepada orang lain. Adapun Menurut Stanton, marketing adalah, seluruh sistem aktifitas usaha yang didisain mulai dari perencanaan, penentuan harga, promosi dan distribusinya, dalam rangka memuaskan target pasar untuk keuntungan perusahaan. ${ }^{7}$

Pendekatan Marketing yang digunakan oleh beberapa perusahaan, telah terbukti dapat merubah prilaku konsumen dan mendorong banyak orang, untuk membeli suatu produk. Marketing sebagai cabang ilmu ekonomi, belakangan ini tidak hanya digunakan untuk memasarkan produk barang atau jasa. Bahkan ia telah diaplikasikan dalam usaha memasarkan suatu gagasan atau ide, yang

7 Lihat, Philip Kotler, Marketing Management: Millenium Edition (New Jersey: Prentice Hall Inc., 2001), 4. Bandingkan dengan, William J. Stanton, dkk, Fundamental of Marketing (New York: McGraw-Hill, 1994), p. 7 . biasa disebut dengan istilah Sosial Marketing.

Sosial marketing" memiliki makna yang tak jauh dari arti kata "pemasaran" dalam dunia bisnis. Pada awalnya Sosial marketing mengacu pada penerapan strategi pemasaran, yang digunakan untuk membantu memecahkan beberapa masalah sosial dan kesehatan masyarakat, Berkaca pada kenyataan bahwa, teknik dan strategi pemasaran secara luar biasa telah berhasil mendorong masyarakat untuk membeli sebuah produk. Maka secara teori para ahli melihat, bahwa teknik-teknik menjual semacam itu, juga bisa diadaptasi untuk "menjual” gagasan dan perilaku, dalam rangka meningkatkan kualitas hidup masyarakat. Hal ini didasarkan pada asumsi bahwa, beberapa permasalahan sosial seperti penyebaran HIV atau tingkat kecelakaan lalu lintas yang tinggi, sering disebabkan karena sikap dan perilaku serta cara pandang yang terlanjur salah dan harus dirubah

Akan halnya dengan kegiatan sosialisasi atau promosi ajaran agama, Menurut Sandra Motner marketing dapat pula diaplikasikan oleh lembaga keagamaan (lembaga yang menjadikan ajaran agama sebagai landasan pergerakannya) dalam usaha untuk merubah prilaku masyarakat ke arah yang sesuai dengan ajaran agama ${ }^{9}$, di antara fungsi tersebut adalah:

8 “. Lihat, Marvin E. Goldberg dan Martin Fishbein, Social Marketing: Theoritical and Practical Perspectives (New Jersey: Lawrence Erlbaum Associates, 2008), p. 4-6. 9 Sandra Mottner, "Marketing and Religion," di dalam The Routledge Companion to Nonprofit Marketing, ed. Adrian Sargeant (London: Taylor \& Francis Routledge, 2008), p. 98. 
1) Menarik audien agar mau mengikuti ajaran agama.

2) Membangun loyalitas kepada agama.

3) Meningkatkan tingkat kesadaran beragama, sesuai dengan normanorma yang diakui dalam agama.

4) Meningkatkan penghayatan terhadap keyakinan beragama.

5) Meningkatkan dukungan keuangan terhadap kegiatan organisasi agama.

Perubahan yang diinginkan dalam proses marketing adalah perubahan prilaku pada tingkat kelompok atau individu. Sudah barang tentu, semua peubahan yang direncanakan berasal dari perubahan individu terlebih dahulu. Dalam hal ini maka perubahan yang disasar pertama, berada pada tingkat keyakinan mendasar dari individu. Dengan demikian peran kegiatan promosi dengan memanfaatkan media menjadi sangat penting, Walaupun ia bukan faktor penentu dalam marketing, akan tetapi ia akan menjadi sarana komunikasi efektif, dalam usaha merubah sikap dan prilaku calon pendonor ${ }^{10}$.

\section{Pemanfaatan Media dalam Religious Marketing}

Dalam praktek dakwah Islam, pendekatan marketing (dalam bentuknya yang modern dan dalam proses promosinya menggunakan sarana media), telah diaplikasikan oleh beberapa

10 Richard Jackson Harris, Cognitive Psycology of Communication (New Jersey: Lawrence Erlbaum Associates, Inc., 2004), 344. Bandingkan dengan Philip Kotler dan Nancy R. Lee, Marketing in the Public Sector : A Roadmap for Improved Performance (New Jersey: Wharton School Publishing, 2007),p. 191 lembaga/institusi yang berbasis agama Di antara lembaga ini adalah, lembaga pengelola dana filantropi ummat, lembaga keuangan syariah (Perbangkan, asuransi), Travel umroh dan haji, lembaga pendidikan dan social keagamaan begitu pula lembaga politik yang telah menggunakan symbol-simbol keagamaan, sebagai landasan atau filosofi organisasi.

Pembahasan tentang peran media dalam mengkomunikasikan ajaran agama telah menjadi perhatian para ilmuan. Setidaknya, ada dua pendekatan, yang mendasari pembahasan, tentang hubungan antara media dan agama.

Yang pertama adalah Dualisme yaitu, pandangan yang memisahkan hubungan antara media dan agama. Mereka berasumsi bahwa wilayah yang ditampilkan oleh agama dan media, berada pada dua sisi yang berbeda. Asumsi ini, berdasarkan teori Durkheim yang menjelaskan, tentang adanya garis pemisah antara yang sakral dan profan dalam kehidupan sosial ${ }^{11}$. Menurut John Fiske, Media berada di tengah kehidupan modern yang sangat rasional dan sekuler. Oleh karena itu, segala analisis tentang media, audiens dan lain sebagainya harus berdasarkan konsep yang murni sekuler. ${ }^{12}$

Ketika media menampilkan konten religius, hal itu akan berpotensi menimbulkan polemik. Karena audien dari suatu media masa, menurutnya, tidak memiliki karakter yang homogen. Mereka memiliki basis perbedaan yang heterogen,

${ }^{11}$ Stewart M. Hoover, Religion in the Media Age: Religion, Media, and Culture Series (New York: Taylor \& Francis Routledge, 2006), p. 69.

12 John Fiske, Television Culture: Studies in Communication Series (London: Taylor \& Francis Routledge, 1987), 66. 
baik dari sisi status sosial, gender, warna kulit, suku, agama, pemahaman, keyakinan dan lainnya. Dengan demikian media telah melakukan diskriminasi dan akan memunculkan perasaan, bahwa mereka menjadi subordinat, dari suatu sistem sosial yang dominan. Akibatnya mereka akan resisten terhadap konten dan media yang ada. ${ }^{13}$ Ini merupakan salah satu argumen yang diajukan yang menjelaskan mengapa agama tidak dapat begitu saja masuk ke dalam media.

Menurut M Hoover, sebagaimana dikutip oleh Jackson Harris, setidaknya ada 5 alasan, yang menjadikan media harus mengambil jarak dengan agama :

1) Pandangan yang menyatakan bahwa ketika masyarakat semakin modern, mereka akan bersikap lebih sekuler dan semakin menjauh dari agama.

2) Agama merupakan masalah, yang berada pada wilayah individu yang tidak perlu disentuh oleh publik.

3) Agama memiliki klaim yang berada di luar wilayah empirik.

4) Beberapa masalah agama, sangat kompleks dan agak berat untuk dibawa ke ruang publik.

5) Beberapa masalah agama dapat memunculkan perdebatan berkepanjangan. ${ }^{14}$

Argumen di atas cukup beralasan untuk diperhatikan. Namun argumen tersebut belum memadai, untuk dijadikan landasan mendasar, dari masalah hubungan antara agama dan media. Ketika media harus berhadapan dengan

13 John Fiske dan John Hartley, Reading Television (London: Taylor \& Francis Routledge, 1978), 80. dan lihat pula, John Fiske, Television Culture ...,p. 16.

14 Richard Jackson Harris, Cognitive Psychology of Comunication ..., p. 341. perkembangan dan kebutuhan mutahir dari masyarakat, maka gagasan kedua berikutnya yang muncul adalah tranformasionisme. ${ }^{15}$

Para ilmuan melihat bahwa perkembangan tekhnologi mutakhir dan globalisasi yang berlangsung belakangan ini, telah berpengaruh terhadap cara pandang media terhadap agama, juga sebaliknya ${ }^{16}$. Dunia saat ini telah menjadi "desa global" (global village). Media, dituntut untuk ikut berperan dalam membentuk kesadaran social. ${ }^{17}$.Oleh karena itu, ia perlu menyampaikan seluruh hal yang terjadi di panggung dunia global, baik di depan layar atau yang berada di belakang layar. Hal ini berjalan, bersamaan dengan semakin meningkatnya level pengetahuan dan pendidikan masyarakat. Menurut mereka, media perlu mengambil peran, dalam usaha membenahi pemahaman agama di tengah kehidupan modern. ${ }^{18}$

Ditambahkan lagi oleh Hoover bahwa, pandangan dualisme memiliki keterbatasan: Pertama, bagi masyarakat yang memilki kesadaran beragama, ${ }^{19}$

Stewart M. Hoover, Religion in the
Media Age..,p. 68.
16 Stewart M. Hoover, Religion in the
Media Age...,p. 11.
17 Marshal McLuhan, Understanding
Media: the Extensions of Man (London: Taylor \& Francis Routledge, 1964), p. 37.

18 Dengan konsep "Medium is massage" McLuhan menjelaskan tentang betapa pentingnya peran media dalam kehidupan modern. Karena media, manusia dapat saling memahami antara satu dengan lainnya. Baca, Marshal McLuhan., Understanding Media ..., 151 Baca pula, Stewart M. Hoover ..., Religion in the Media Age...,p. 11.

19 Baca, Warren S. Goldstein, Marx, Critical Theory, And Religion: A Critique of Rational Choice: Studies in Critical Social 
mereka merasa kurang nyaman dengan kategorisasi dualistik, yang memisahkan antara agama dan media seperti yang berlangsung

Kehadiran agama, akan selalu melekat di tengah masyarakat modern, karena beberapa hal. Di antaranya;

a. Agama memberikan kepuasan emosional bagi pemeluknya

b. Penganut agama mendapatkan status sosial dalam komunitasnya.

c. Agama memberikan penjelasan terhadap sesuatu yang rumit untuk difahami.

d. Agama menjanjikan kehidupan yang lebih baik. ${ }^{20}$

Kedua, perkembangan mutahir yang ada. Di mana, konten yang sebelumnya, dianggap sebagai media sekuler, berangsur telah menjadi semakin religius. Begitu pula agama, dalam beberapa aspek ia telah dapat melakukan adaptasi terhadap hal-hal yang bersifat sekuler. $^{21}$

Hubungan antara agama dan media, dapat terlihat lebih jelas, ketika simbol-simbol agama pada saat ini, dapat diterima di ruang media. Maraknya lagulagu bertema religius, yang telah masuk ke ruang publik dan dapat diterima masyarakat dengan baik. Media massa pun tidak ketinggalan, dengan berbagai proyek dan program, yang menyisipkan

Sciences (Leiden: Koninklijke Brill NV, 2006), p. 288.

20 Baca, Warren S. Goldstein, Marx, Critical Theory, And Religion: A Critique of Rational Choice: Studies in Critical Social Sciences (Leiden: Koninklijke Brill NV, 2006), p. 288.

Media Age..., 75 . tema spiritual dan transenden ke dalamnya. ${ }^{22}$

Model tranformasionisme Hoover, telah memberikan peluang bagi proses promosi dalam marketing ajaran agama. Di mana, media memberi ruang bagi agama. Dan agama melakukan penyesuaian, agar ia dapat masuk ke dalam media. Namun konsep Modifikasi dan penyesuaian ini tidak mudah dilakukan, karena hal itu memerlukan kejelian dan ketepatan dalam memutuskan strategi yang tepat. ${ }^{23}$

\section{Penutup}

Tidak dipungkiri kalau media memiliki pengaruh kuat dalam proses marketing. Tapi perlu diketahui bahwa walaupun media memiliki posisi yang penting, ia tidak akan bisa bergerak sendiri. Masih ada beberapa komponen lain dari 4P (Product, Price, Place dan Promotion, ditambahkan Proses). Yang juga perlu diperhatikan dan dijadikan pertimbangan.

22 Stewart M. Hoover dan Lynn Schofield Clark, Practicing Religion in the Age of the Media. (Columbia: Columbia University Press, 2002), p. 1.

${ }^{23}$ Menurut Keith A. Robert: Prinsip marketing yang menyatakan "Produk harus berubah agar dapat sesuai dengan kebutuhan yang diminta"memberikan tantangan tersendiri bagi proses marketing ajaran agama. Lihat, Keith A. Robert, Religion in Sociological Perspective (Canada: Wadsworth, 2004), p. 348. 


\section{DAFTAR PUSTAKA}

Dedy Djamaluddin Malik, Komunikasi Persuasif. (Bandung:Remaja Rosdakarya,1994).

Mara Einstein, Brands of Faith: Marketing Religion in a Commercial Age: Religion, Media and Culture (Canada: Taylor \& Francis Routledge, 2008).

Philip Kotler dan Nancy R. Lee, Marketing in the Public Sector: A Roadmap for Improved Performance (New Jersey: Wharton School Publishing, 2007).

Sandra Mottner, "Marketing and Religion," di dalam The Routledge Companion to Nonprofit Marketing, ed. Adrian Sargeant. (London: Taylor \& Francis Routledge, 2008).

Stewart M. Hoover, Religion in the Media Age: Religion, Media, and Culture Series (New York: Taylor \& Francis Routledge, 2006). 